\title{
Ergonomic adequacy of the baby nursery of child development center located in UFSC - Florianópolis
}

\author{
Lizandra Garcia Lupi Vergara $^{\mathrm{a}}$ and Lucie Elisa Ribet ${ }^{\mathrm{b}}$ \\ ${ }^{a, b}$ Production and Systems Engineering Department, Federal University of Santa Catarina, Campus Universitário \\ Reitor João David Ferreira Lima Trindade, CEP: 88040-970, Florianópolis, SC, Brazil
}

\begin{abstract}
A study in the educators' work station at baby nursery of NDI/UFSC, located in Florianópolis, was conducted using the Work Ergonomic Analysis methodological tool. The demand considered was the educators' physical exhaustion caused by the weight carried when taking care of the babies, the postures assumed during the labor activity and the spatial arrangement of the baby nursery. Thinking ergonomically, the spatial arrangement is directly associated to three factors: the formal aspect of the environment, the esthetic aspect including colors and finish quality and the ease of understanding involved in the baby nursery labor. By the ergonomic adequacy it is possible to assert that if were established better conditions of posture and comfort for the educators, as well as satisfactory technical and operational information to carry out the activities, greater safety and welfare would be provided to the babies, the main focus of the work.
\end{abstract}

Keywords: Ergonomics, posture, comfort, safety

\section{Introduction}

Working with babies is a very demanding task that requires special care and attention and that is still little known by outsiders. In this sense, it was decided to perform a study at the NDI (Child Development Center) of UFSC, structure that welcomes children from 0 to 2 years of age. The demand considered was the educators' physical exhaustion and the inadequacy of the nursery spatial arrangement. Physical exhaustion is mainly due to the constant weight carried while manipulating the babies and to the positions adopted during the work activity. From an ergonomics perspective, the spatial arrangement refers to the formal aspect of the environment, in terms of aesthetics - color and finish quality - and easiness of understanding the information involved during the working activities. The NDI baby nursery offers a twenty-two square meter area that can receive up to seven babies being cared by two or three adults. The educators work in five-hour shifts, five days a week, plus an extra half-day. The most critical situation is encountered during days of full atten- dance, when two educators are present to attend seven babies. An overview of the nursery and the layout of the furniture can be seen in Figure 1.

\section{Methodology}

This study was conducted following the four steps of the AET methodology: identification of the demand to be considered, analysis of the activities, diagnostic and proposal of ergonomics recommendations. The analysis takes into consideration the division into the three ergonomics aspects known as the physical, cognitive and organizational aspects, as recommended by the IEA. In order to evaluate the major obstacles encountered daily by the educators, were applied various methodological tools. The collect of the data was conducted through:

- Interviews of four educators of the nursery;

- Observations of the postures assumed by the educators during the tasks of feeding, changing, putting to sleep and teaching the babies; 
- The measurement of environmental variables, such as temperature, noise level and illumina- tion;

- The application of the ITERSRi checklist.
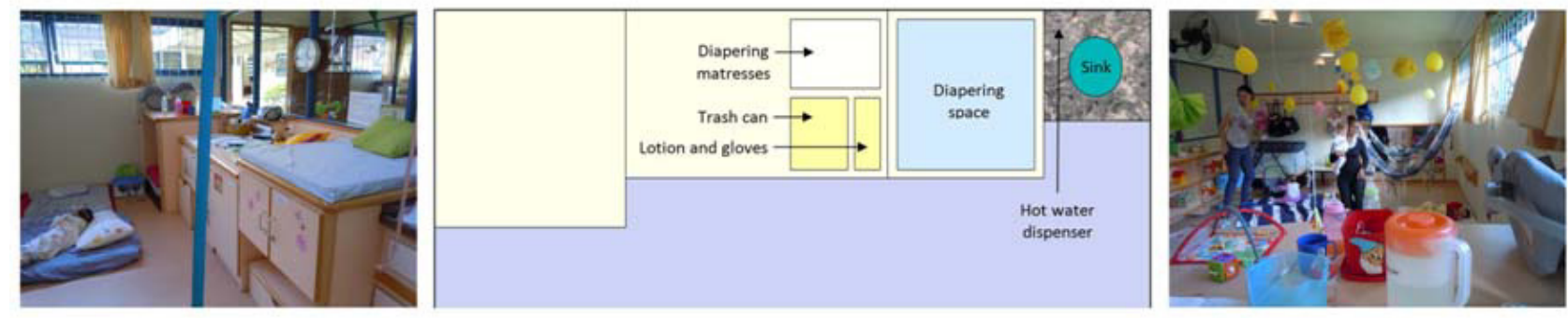

Figure 1 - Nursery overview and layout

Then, the different stages of the labor activity were analyzed using the [6] REBA and RULA ergonomics methods, allowing us to determine the critical postures assumed by the educators. Finally, the design of solutions was developed in adequacy with the product requirements based upon the [2] methodology of ergonomics lecture of the product.

\section{Activities analysis}

The educators' work consists of taking care of the babies according to the zero-to-one year teaching procedure. This task can be broken down into four sub-tasks that correspond to the moments requiring more attention from the educators, in other words: feeding, changing diaper, putting to sleep and playing with the babies. Each of those sub-tasks has been attentively observed and split into a sequence of activities. Then, a detailed description of the postures assumed while executing those activities has been proposed. Figure 2 illustrates some postures adopted by the educators while performing those daily tasks. From the sequence of postures obtained, six appeared to be more critical and have been submitted to further analysis using the REBA (Rapid Entire Body Assessment) and RULA (Rapid Upper Body Assessment) methods.

\section{Diagnostic}

As a result of the analysis conducted, three physical aspects appeared to be inadequate and source of discomfort during the labor: the postures assumed by the educators, the spatial arrangement of the nursery and the noise level. The interviews and observations clearly highlighted inadequate postures that induce discomfort and backache for the educators, result also confirmed by both the REBA and RULA methods. The nursery layout appeared to be a restriction in the children learning and discovering. The furniture offer few alternatives of spatial arrangement and are not suitable for adults. The educators pointed out excessive noise in the nursery that disturbs both babies and adults. Noise measurement showed an average of $75 \mathrm{~dB}$, far above the recommended $20 \mathrm{~dB}$ for sleeping room. 

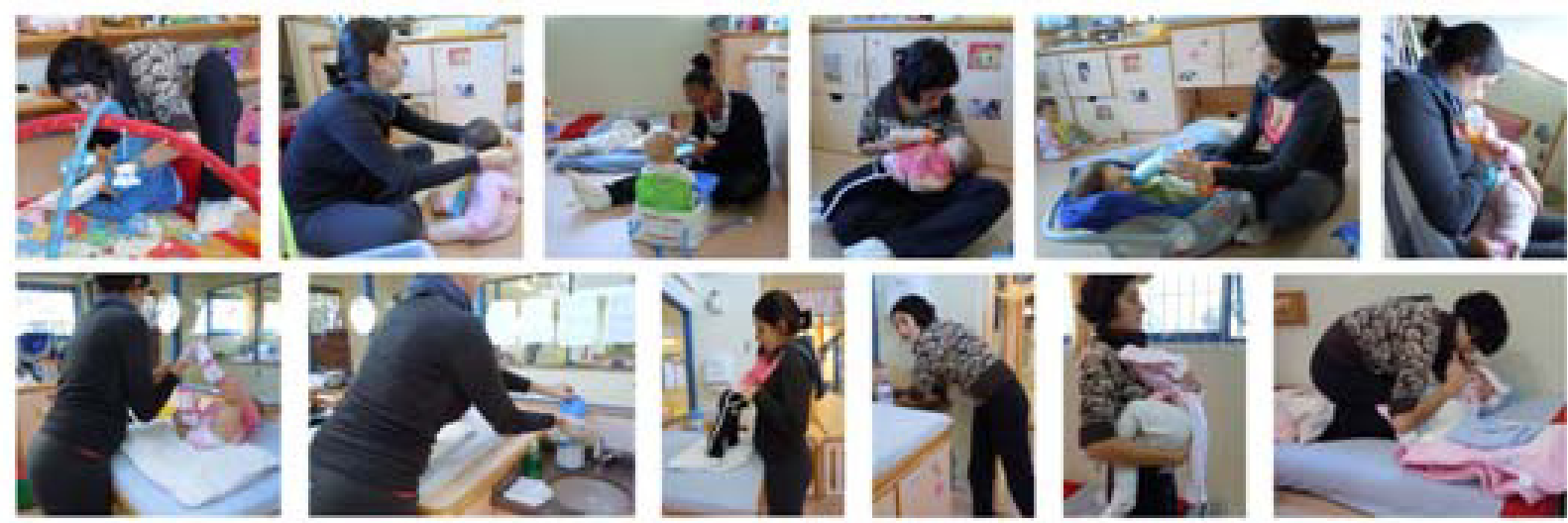

Figure 2 - Postures assumed by the educators during the daily activities

\section{Ergonomics recommendations}

In regards of the physical inadequacy of the nursery, various ideas of improvement have been submitted, such as:

- An interactive wall panel: decorative mural aiming to develop the children's senses and including various textures, colors, shapes and sounds. The panel will provide handles to help the babies to stand up;

- A dismountable foam cube with pieces that can be used by adults as a seat and by kids as a toy;

- A reorganization of the furniture to facilitate the movements of the educators during the main tasks. That includes a new design of the diaperchanging area;

- The creation of a window at ground level for the babies to look onto the outside;

- The integration of a sound-absorber dispositive to improve the acoustic comfort of both children and adults.

\section{Conclusion}

By the application of the Work Ergonomics Analysis method, it has been possible to identify the main source of discomfort daily encountered by the educators of the NDI baby nursery. It has been clearly revealed that the physical aspect was critical. That re fers to the inadequate postures assumed by the educators, the lack of practicability of the spatial arrangement and a high noise level. In response to this inadequacy were proposed various solutions that intend to improve the environment for both the babies and the adults. Further cost and applicability analysis are yet to be carried out before the implementation of the solutions proposed.

\section{References}

[1] I. Iida, Ergonomia: Projeto e Produção, Edgard Blücher, São Paulo, 2005.

[2] J. Gomes Filho, Ergonomia do objeto, Escrituras Editora, São Paulo, 2003.

[3] Ministério da educação, Educação infantil no Brasil: Avaliação qualitativa e quantitativa, MEC, 2010.

[4] NORMA NBR 10152. Níveis de Ruído para conforto acústico. Available

$<$ www.fat.uerj.br/educacaoambiental/NBR\%2010152-

$1987 \% 20$ n $\%$ EDveis $\% 20$ de $\% 20$ ru $\%$ EDdo $\% 20$ para $\% 20$ confort o\%20ac\%FAstico $\% 5$ B $1 \% 5$ D.pdf $>$.

[5] NORMAS REGULAMENTADORAS NR 15 E NBR 5413/92. Ministério do Trabalho e Emprego. Available at: http://portal.mte.gov.br/legislacao/normas-regulamentadoras$\underline{1 . h t m}$

[6] RULA and REBA methods. Available at: $<$ www.fbfsistemas.com/ergonomia $>$.

[7] S. W. Abib, Transdisciplinaridade na relação complexa entre Pedagogia e mobiliário no Núcleo de Desenvolvimento Infantil, Dissertaçao de mestrado - UFSC, Florianopolis, 2001

[8] T. Harms, Infant/toddler environment rating scale - iters. Frank Porter Graham Child Development Center, University of North Carolina at Chapel Hill, 1990. Teachers College Press. 